J. Perinat. Med. 16 (1988)

\section{Immunoglobulin levels in maternal and neonatal sera from normal and abnormal pregnancies}

\author{
Patricia Medina-Gómez ${ }^{1}$, David J. H. Brock ${ }^{1}$, Caroline Hayward', David Bedgood ${ }^{1}$, \\ William H. McBride ${ }^{2}$, Estela Quiroz ${ }^{3}$, Roberto Guevara ${ }^{3}$, Humberto Joachin ${ }^{3}$, and \\ Samuel Karchmer ${ }^{3}$ \\ ${ }^{1}$ Department of Human Genetics, University of Edinburgh, U.K. \\ ${ }^{2}$ Department of Radiation Oncology and JCCC, University of California, Los \\ Angeles, U.S.A. \\ ${ }^{3}$ Hospital de Gineco-Obstetricia No. 4, IMMS, Mexico
}

\section{Introduction}

The etiology of congenital malformations is most often obscure. About one third of all congenital malformations recognizable at birth are of the nervous system and the majority are neural tube defects (NTD) [21]. The etiology of NTD is multifactorial [7] but some cases may be associated with infection such as during influenza epidemics $[11,15]$. In Japan [33], a regional high incidence of anencephaly was associated with a double infection by cytomegalo and coxsackie virus. EMERY [12] found lymphoreticular aggregates in newborn lungs only in those cases of intrauterine infections and meningocele or anencephaly. Along with others $[2,17,23]$, we have been considering the possibility that immune responses to infectious agents or the agents themselves may contribute to deffective development. Fetuses and neonates respond poorly to infections as well as to test antigens [28]. Although the fetus starts synthesizing $\operatorname{IgG}$ at 12 weeks of gestation and although there is some IgM production in late gestation that can be stimulated by intrauterine infection, the fetus and newborn rely in large part upon maternal transplacental IgG to ward off infection $[13,14]$.

The aim of this study was to examine the possible association between the immune systems, infection and NTD by specifically analyzing mothers and their neonates, measuring IgG, IgM and albumin in three groups: congenital malformations, open NTD and matched controls.

\section{Curriculum vitae}

Patricia Medina-Gómez, M.D., M.Sc., Ph.D., was born in Mexico City in 1953. From 1972 to 1977, she studied medicine in La Salle University, Mexico City. In 1979 she received her M.Sc. in Human Genetics and in 1982 her Ph.D. in Human Genetics from the University of Edinburgh, Scotland. Since

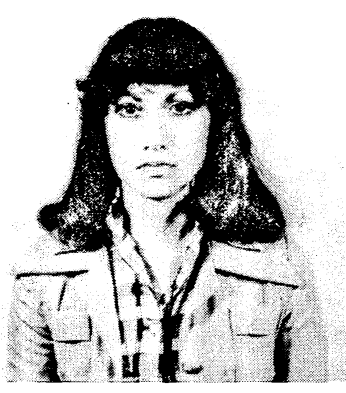
march 1983, she has been working at the National Institute of Perinatology in Mexico City.

\section{Materials and methods}

The samples were taken at the Hospital de GinecoObstetricia No. 4, IMSS, in Mexico City with the mothers' consent. They were coded and the assays were performed in a blind trial by members of the Department of Human Genetics, University of Edinburgh. The three groups studied consisted of:

1) Ten cases of NTD (according to the main abnormality these were: 4 cases of anencephaly, 4 of spina bifida, and 2 of encephalocele).

2) Three cases of congenital malformations (hydrocephaly, caudal appendage, and sacral tumor). No evidence of spina bifida occulta was found on $\mathrm{X}$-ray examination in any of these three cases. 
Although no correlation exists between fetal alpha-fetoprotein (AFP) and IgG levels in cord sera [8], these malformations were chosen because elevated amniotic fluid AFP has previously been associated with some cases of hydrocephaly and minor congenital malformations $[6,18,24]$ and because of the association between germ cell tumors in children and NTD in the stillborn siblings [3].

3) Twenty two matched controls. Controls were matched to the abnormal by the age of the mother \pm 3 years, number of pregnancies, gestational age and sex of the neonate.

Peripheral blood was taken from the neonates and mothers within 72 hours following birth. In the NTD group one case was a stillbirth and blood was obtained by heart puncture. All the groups were divided according to gestation in preterm ( $<37$ weeks), term (37-41 weeks) and post-term (42 weeks or more). The gestational age assessment was according to the date of last menstrual period, proper matched controls were important due to the differences in IgG and IgM levels found by other authors regarding gestational age $[4,28$, 30].

\subsection{Measurement of IgG}

Tri-Partigen-IgG plates (Behring) were used to determine IgG levels by radial immunodiffusion. Standard human serum (Behring) and sample sera were diluted 1:10 in phosphate-buffered-saline (PBS). Five microliters of each dilution were used per test, and the plates were allowed to diffuse for 50 hours at room temperature before measurements of diffusion were made.

\subsection{Measurement of IgM}

A two-step enzyme-linked-immunosorbent assay (ELISA) was used to determine IgM levels. Wells of immunoassay plates were coated with $0.1 \mathrm{ml}$ anti-human IgM (Dako) diluted $1 / 100$ with $0.1 \mathrm{M}$ $\mathrm{NaHCO}_{3}, \mathrm{pH}$ 9.0. The plates were incubated for three hours at 37 degrees centigrades then washed six times in $0.9 \%$ saline containing $0.05 \%$ Tween 20 (Koch-Light Labs). Standard human serum $(0.1 \mathrm{ml})$ or $0.1 \mathrm{ml}$ of sample, diluted $1 / 100$ in PBS containing Tween was added to the respective wells and incubated for one hour at 37 degrees centigrades. The plates were again washed six times in saline containing Tween. Peroxidaselinked anti-human IgM (Miles-Yeda Ltd.) diluted $1 / 200$ in PBS-Tween was added to all wells and the plates incubated for one hour at 37 degrees centigrades. The plates were washed and $0.05 \mathrm{ml}$ of o-phenylenediamine (Sigma) $(40 \mathrm{mg}$ in $100 \mathrm{ml}$ of $0.1 \mathrm{M}$ citrate-phosphate buffer $\mathrm{pH} 5.0$ ) was added to all wells, followed by $0.05 \mathrm{ml}$ of $\mathrm{H}_{2} \mathrm{O}_{2}(5$ microliters of $100 \mathrm{vol}$. in $100 \mathrm{ml}$ citrate-phosphate buffer $\mathrm{pH}$ 5.0). The plates were incubated at room temperature ( 20 degrees for 30 minutes. The reaction was stopped by adding $0.05 \mathrm{ml}$ of $4 \mathrm{M} \mathrm{H}_{2} \mathrm{SO}_{4}$. The O.D. was read on a Titertek Multiskan at $492 \mathrm{~nm}$. Values were determined by comparison with O.D.'s of the standards.

\subsection{Measurement of albumin}

An antiserum to human albumin was used (Dako) at a concentration of $1 \%$ in rocket immunoelectrophoresis. Standard human serum and the samples were diluted 1/300 in PBS and 5 microliters of each applied. Electrophoresis was performed at $2.5 \mathrm{~V} / \mathrm{cm}$ for 16 hours at 4 degrees centigrades. Plates were washed, dried and then stained in $0.5 \%$ kenacid blue (BDH) in 5:5:1 methanol: $\mathrm{H}_{2} \mathrm{O}$ : acetic acid. The albumin values were determined by measurement of the area under the rockets as compared with standard serum values.

\section{Results}

Neonates with NTD had significantly lower IgG levels than controls (table I), while their mothers had significantly elevated levels. The mother/neonate $(\mathrm{M} / \mathrm{N})$ ratio, which was established for each pair (therefore checks the consistency of the mother-fetus system), was significantly higher than the controls $(p<0.025)$. IgG levels in sera from three neonates with other congenital malformations and their mothers were within the normal range.

Immunoglobulin $M$ did not show any significant changes in the NTD groups. However, in three neonates with congenital malformations (table II), IgM levels were significantly $(\mathrm{p}<0.01)$ higher and their $\operatorname{IgM} \mathrm{M} / \mathrm{N}$ ratio were significantly $(p<0.01)$ lower than the controls. This prompted the investigation of a possible intrauterine infection in the neonates with congenital malformations. Sera from these neonates and their mothers were assayed by complement fixation for antibodies to influenza A and B, B. abortus, leptospira, adenovirus, $Q$ fever, respiratory syncitial virus, M. pneumoniae, mumps virus (S and V), herpes simplex, measles, cytomegalovirus and psittacosis. 
Table I. Serum IgG $(\mathrm{mg} / \mathrm{ml})$ levels of neonates with NTD and other congenital malformations and of their mothers

\begin{tabular}{|c|c|c|c|c|c|c|c|}
\hline & \multirow[t]{2}{*}{$\mathrm{N}$} & \multicolumn{2}{|c|}{ Maternal } & \multicolumn{2}{|c|}{ Neonatal } & \multicolumn{2}{|c|}{$\mathrm{M} / \mathrm{N}$ ratio } \\
\hline & & Median & Range & Median & Range & Median & Range \\
\hline Congenital malformations & 3 & 15.5 & $10.2-19.0$ & 14.1 & $11.5-20.1$ & 0.77 & $0.72-1.65$ \\
\hline Open NTD & 10 & $* 16.3$ & $11.5-19.6$ & $* * 10.7$ & $5.2-12.8$ & $* * 1.51$ & $1.00-3.77$ \\
\hline Controls & 22 & 11.9 & $7.9-24.4$ & 12.1 & $7.2-18.8$ & 1.00 & $0.57-2.61$ \\
\hline
\end{tabular}

$* \mathrm{p}<0.05$.

** $\mathrm{p}<0.025$. Using a one tailed Mann-Whitney $U$ test comparing the groups of congenital malformations or open NTD with controls.

Table II. Serum IgM (mg/ml) levels of neonates with NTD and other congenital malformations and of their mothers

\begin{tabular}{|c|c|c|c|c|c|c|c|}
\hline & \multirow[t]{2}{*}{$\mathrm{N}$} & \multicolumn{2}{|l|}{ Maternal } & \multicolumn{2}{|c|}{ Neonatal } & \multicolumn{2}{|c|}{$\mathrm{M} / \mathrm{N}$ ratio } \\
\hline & & Median & Range & Median & Range & Median & Range \\
\hline Congenital r & 3 & 0.670 & $0.480-0.990$ & ${ }^{*} 0.115$ & $0.096-0.241$ & *6.97 & $1.97-8.57$ \\
\hline Open NTD & 10 & 0.827 & $0.720-1.120$ & 0.074 & $0.024-0.129$ & 12.85 & $7.31-32.79$ \\
\hline Controls & 22 & 0.844 & $0.410-1.450$ & 0.063 & $0.025-0.136$ & 14.56 & $4.78-26.57$ \\
\hline
\end{tabular}

* $\mathrm{p}<0.01$. Using a one tailed Mann-Whitney U test comparing the groups of congenital malformations or open NTD with controls.

Table III. Serum albumin $(\mathrm{mg} / \mathrm{ml})$ levels of neonates with NTD and other congenital malformations and of their mothers

\begin{tabular}{|c|c|c|c|c|c|c|c|}
\hline & \multirow[t]{2}{*}{$\mathrm{N}$} & \multicolumn{2}{|l|}{ Maternal } & \multicolumn{2}{|c|}{ Neonatal } & \multicolumn{2}{|c|}{$\mathrm{M} / \mathrm{N}$ ratio } \\
\hline & & Median & Range & Median & Range & Median & Range \\
\hline Congenital malformations & 3 & 28.2 & $14.9-33.2$ & 32.9 & $26.5-49.2$ & 0.57 & $0.45-1.25$ \\
\hline Open NTD & 10 & $* 32.4$ & $28.0-39.2$ & 33.0 & $20.2-58.0$ & 0.95 & $0.57-1.64$ \\
\hline Controls & 22 & 26.1 & $16.8-37.3$ & 27.8 & $15.4-46.3$ & 0.89 & $0.36-1.58$ \\
\hline
\end{tabular}

* $\mathrm{p}<0.001$. Using a one tailed Mann-Whitney $U$ test comparing the groups of congenital malformations or open NTD with controls.

In no case was there $>1 \log _{2}$ difference between mother and neonate, and therefore no evidence that the neonates were infected by these agents.

Albumin was measured as an index of serum concentration. It was significantly $(p<0.001)$ increased in the maternal sera of the NTD group compared to the controls (table III). In view of this finding, data were analyzed according to the type of delivery: cesarean section (5 NTD, 8 controls) or normal delivery (5 NTD, 14 controls). There were significant differences between the NTD and control group whether delivery was normal $(p<0.02)$ or by cesarean $(p=0.005)$.

\section{Discussion}

Our results agree with those of KAMRIN [20] who also found high IgG levels in mothers of spina bifida children. Their sera reacted with human spinal cord antigens and their injection into the lumen of the uterus of rats, adjacent to implantation sites, produced varying degrees of skeletal and soft tissue malformations among viable survivors.

Our finding that infant IgG levels were depressed in NTD but not in other congenital abnormalities is of interest. Mc KAY et al. [22] had previously shown low levels of IgG in neonates with a variety 
of malformations, but our data point to the value of not placing all heterogeneic congenital malformations, which may have many different etiologies, within one group. Mc KAY et al. concluded that hemodilution could be one cause of the lowered IgG levels. We found no significant difference in the albumin levels between control and NTD neonates. Leakage of IgG from the open NTD is not the reason for the low IgG levels. It should be noted that albumin levels tended to be elevated in the NTD group, maternal and neonatal sera. The opposite association has been observed in Down patients, high serum gammaglobulin, low albumin and low AFP, a common regulatory mechanism for AFP and albumin has been suggested [32].

$\mathrm{IgG}$ in neonates is mostly maternal in origin, although low levels can be contributed by the fetus. It would be of interest to know the contribution of the fetus to IgG levels in cases of NTD, which could be done by allotype analysis. Fetal immunodefficiency, such as can occur following intrauterine infection with rubella [26, 27]; or as a result of a response to paternal allotypic determinants, is unlikely to be a major cause of the low neonatal IgG levels in NTD. Other factors such as the extent of placental transfer of maternal IgG and its disappearance from the fetal circulation are more likely explanations.

The fetal IgG concentration is $5.8 \%$ of the maternal level until after 17 to 22 weeks when it rises to $10-20 \%$. After 26 weeks it equals the maternal concentration [16]. These changes are the result of alterations in placental permeability and maturation of specific IgG carrier mechanisms which involve placental macrophages $[5,16,19,31]$. Ab- normal functional assays in the placental barrier, perhaps involving placental macrophages may be the main reason for the low fetal IgG levels in NTD. In this regard, it is of interest that elevated number of macrophages [29], placental immaturity [1] and increased amniotic fluid macrophages $[10,23,25]$ have been associated with anencephaly. This abnormal macrophage activity may affect the ongoing maturation process or could be responsible for malformation of the IgG transport mechanism.

The high IgG levels in maternal NTD sera and the low level in their neonates resulted in a high $\mathrm{M} / \mathrm{N}$ ratio. Our control values are similar to those in previous studies which gave values of $\mathrm{IgG} \mathrm{M}$ / $\mathrm{N}$ ratios from 0.9 to 1.25 at term [4, 28, 30].

Immunoglobulin $\mathrm{M}$, unlike $\mathrm{IgG}$, did not show any significant differences between the levels in the NTD group and the controls. This is in agreement with previous studies [9] of neonates with spina bifida and suggests that intrauterine infection is not a cause of NTD. We have to remember that, although IgM is usually a good parameter for intrauterine infection, a previously raised IgM could be normal at the time of delivery and only in those cases where the virus persists in the tissues throughout pregnancy would IgM be raised [22]. In contrast to NTD, the neonates with other congenital malformations had significantly elevated IgM levels and a lower $\mathrm{M} / \mathrm{N}$ IgM ratio. No differences were found between maternal and neonate sera in their antibody levels to a variety of infectious agents. The three cases of congenital malformations were delivered at term and it is interesting that BoERSMA [4] found a similar low ratio in a preterm group.

\section{Abstract}

IgG, IgM and albumin levels in sera from neonates with open neural tube defects (NTD), other congenital malformations, and matched controls were measured, as were levels in sera from their mothers. Neonates with NTD had significantly lower serum IgG levels than 22 control neonatal sera. On the other hand, the mothers of these neonates with NTD had elevated serum IgG levels resulting in a striking imbalance in the mother/ neonate IgG ratio. In contrast to IgG, IgM levels in maternal and neonatal sera from the NTD group were within normal values. The maternal albumin levels were
}

however significantly increased reflecting hemoconcentration.

In sera from 3 neonates born with other congenital malformations (hydrocephaly, caudal appendage and sacral tumor) the only significant changes were higher IgM levels and lower mother/neonate IgM ratios. These results are discussed in the context of materno-fetal immune responses, placental transfer of plasma proteins and the possible involvement of immunoglobulins in fetal malformation.

Keywords: Congenital malformations, immunoglobulins, maternal, newborn. 


\section{Zusammenfassung}

Immunglobulinspiegel im maternalen und neonatalen Serum bei normalen und gestörten Schwangerschaften

Die Ätiologie kongenitaler Mißbildungen ist in den meisten Fällen unbekannt. Etwa ein Drittel ist bei der Geburt erkennbar und die meisten Fälle betreffen Neuralrohrdefekte (NTD, neural tube defect) [21]. Man nimmt ein multifaktorielles Geschehen an [7] und viele Arbeiten weisen darauf hin, daß intrauterine Infektionen oder immunologische Vorgänge die Ätiologie mit beeinflussen $[2,11,12,15,17,23,32]$.

Ziel dieser Studie war es, die möglichen Zusammenhänge zwischen dem Immunsystem, Infektionen und NTD genauer zu untersuchen. Dazu wurdn die IgG-, IgM- und Albuminspiegel bei den Müttern und ihren Neugeborenen bestimmt, wobei 3 Gruppen untersucht wurden: offene NTD (10 Fälle, davon 4 mit Anencephalus, 4 mit Spina bifida und 2 mit einer Encephalocele), angeborene Mißbildungen mit geschlossenem Neuralrohr (3 Fälle, davon 1 Hydrocephalus, 1 caudaler Anhang und $1 \mathrm{Sa}$ kraltumor, röntgenologisch in keinem der Fälle Anhalt für Spina bifida occulta) und als dritte Gruppe 22 Kontrollen als matched pairs. Bei der Zuordnung der Kontrollen wurde das Alter der Mutter berücksichtigt ( \pm 3 Jahre), Anzahl der Schwangerschaften, Schwangerschaftswoche und Geschlecht des Neugeborenen. Die IgG-Spiegel wurden mit radialer Immundiffusion bestimmt, das IgM mit Elisa und das Albumin mit Immunelektrophorese. Die statistische Analyse erfolgte nach dem U-Test von Mann und Whitney, wobei die Gruppen mit kongenitaler Mißbildung bzw. Neuralrohrdefekt mit den Kontrollen verglichen wurden. Wir fanden, daß Neugeborene mit NTD signifikant niedrigere SerumIgG-Spiegel hatten als die Kontrolle (Tabelle I). Auf der anderen Seite hatten die Mütter dieser Neugeborenen mit NTD erhöhte Serum-IgG-Spiegel, was zu einer auffälligen Verschiebung der IgG-Ratio Mutter/Kind führte. Hinsichtlich des IgM-Spiegels im maternalen und neonatalen Serum gab es keine Unterschiede zwischen der NTD- und Kontrollgruppe (Tabelle III). Die maternalen Albuminspiegel jedoch waren signifikant, als Ausdruck der Hämokonzentration, erhöht. Im Serum der 3 Neugeborenen mit anderen kongenitalen Mißbildungen war auffällig der höhere IgM-Spiegel bei niedriger IgMRatio Mutter/Kind (Tabelle II).

$\mathrm{Da}$ die 3 Fälle mit anderen kongenitalen Mißbildungen sich von denen mit NTD unterscheiden, unterstreicht die Notwendigkeit einer Trennung der Gruppen: Man kann nicht heterogen kongenitale Mißbildungen mit möglicherweise unterschiedlicher Ätiologie in einer Gruppe zusammenfassen. Die hohen IgG-Spiegel bei Müttern von Kindern mit NTD und die niedrigen IgGSpiegel dieser Neugeborenen werden auch in früheren Arbeiten beschrieben [20,22], wir nehmen jedoch keine Hämodilution als Ursache des niedrigen IgG-Spiegels an. Hinsichtlich des Albuminspiegels gab es zwischen den Neugeborenen mit NTD und den Kontrollen keine signifikanten Unterschiede. Es zeigte sich eine Tendenz zu höheren Albuminspiegeln im maternalen und neonatalen Serum der NTD-Gruppe. Eine mögliche Erklärung für den niedrigen IgG-Spiegel ist eine Änderung der Plazentapermeabilität und die Reifung eines spezifischen IgG-Carrier-Mechanismus, der Plazentamakrophagen mit einschließt. Bei Feten mit Anenzephalus wurde ein erhöhter Gehalt an Makrophagen in der Plazenta [29] und im Fruchtwasser gefunden $[10,23,25]$. Diese abnorme Makrophagenaktivität könnte den Reifungsprozeß beeinträchtigen oder für einen gestörten IgG-Transportmechanismus verantwortlich sein.

Die hohen IgG-Spiegel im maternalen und niedrigen Spiegel im neonatalen Serum der NTD-Gruppe führen zu einer hohen $M / N-R a t i o$. Diese wurde individuell für jedes Mutter/Kind-Paar berechnet und anschließend der Medianwert zur Prüfung des Mutter/Fet-Systems berechnet. Anders als das IgG zeigt das IgM keine Unterschiede zwischen der NTD-Gruppe und den Kontrollen. Im Gegenteil, die Neugeborenen mit anderen kongenitalen Mißbildungen hatten signifikant höhere IgM-Spiegel und eine niedrigere $\mathrm{M} / \mathrm{N}$-IgM-Ratio. Wir fanden jedoch keine Unterschiede zwischen maternalem und neonatalem Serum bezogen auf spezifische Antikörperspiegel, wobei viele Infektionen getestet wurden.

Interessant ist, daß in einer afrikanischen Studie, die Frühgeburten untersuchte, eine ähnlich niedrige Ratio gefunden wurde [4]. Unsere 3 Fälle wurden am Termin entbunden.

Wir berichten lediglich über kleine Fallzahlen. Auf der Basis unserer vorläufigen Ergebnisse (unterschiedliche IgG-Spiegel, spezifische $\mathrm{M} / \mathrm{N}$-Ratios) sind weitere Untersuchungen notwendig, wobei noch einmal auf die Bedeutung von „matched controls“ hingewiesen werden soll.

Schlüsselwörter: Immunoglobuline, kongenitale Mißbildungen, Mutter, Neugeborenes.

\section{Résumé}

Immunoglobulines sériques chez la mère et le nouveau-né, au cours des grossesses normales et pathologiques

L'étiologie des malformations congénitales est le plus souvent obscure. Environ un tiers de l'ensemble des malformations congénitales reconnaisables à la naissance concerne le système nerveux et la majeure partie sont des défects du tube neural (NTD) [21]. On considère que leur étiologie est multifactorielle [7] et certaines observations suggèrent que les infections intra-utérines ou des réponses immunitaires peuvent contribuer à leur étiologie $[2,11,12,15,17,23,32]$.

L'objectif de cette étude est d'approfondir l'association 
possible entre les systèmes immunitaires, l'infection et les NTD en analysant de façon spécifique les mères et leurs nouveaux-nés, en dosant les IgG, les IgM et l'albumine dans les trois groupes: avec malformations congénitales, avec NTD ouvert et témoins appariés. Ces groupes comprenaient: dix cas de NTD (selon l'anomalie prédominante: 4 anencéphalies, 4 spina bifida et 2 encéphalocèles); trois cas de malformations congénitales (hydrocéphalie, appendice caudal et tumeur sacrée, on n'a pas mis en évidence de spina bifida occulta sur les clichés radiographiques dans ces trois cas); vingt deux contrôles appariés. Les contrôles ont été appariés aux anormaux en fonction de l'âge maternel \pm 3 ans, du nombre de grossesse, de l'âge gestationnel et du sexe du nouveau-né. On a mesuré les taux d'IgG par immunodiffusion radiale, les IgM par technique Elisa et l'albumine par immunoélectrophorèse. Les résultats ont été analysés par un test de Mann-Whitney comparant le groupe des malformations congénitales ou le groupe des NTD ouverts avec les témoins. Nous avons trouvé que les nouveaux-nés avec NTD ont des taux sériques d'IgG significativement inférieurs à ceux des 22 sérums des nouveaux-nés témoins (tableau I). D'autre part, les mères de ces nouveaux-nés porteurs de NTD ont des taux d'IgG sériques élevés ce qui entraîne un déséquilibre frappant du ratio d'IgG mère/nouveau-né. A l'opposé des IgG, les taux d'IgM (tableau III) sériques maternels et néonataux dans le groupe NTD se situent dans les valeurs normales. Toutefois, les taux d'albunine maternelle sont augmentés de façon significative ce qui traduit une hémoconcentration. Dans le sérum des trois nouveaux-nés porteurs d'autres malformations congénitales, les seules modifications significatives sont des taux élevés d'IgM et un ratio d'IgM mère/nouveau-né abaissé (tableau II).

Notre résultat, à savoir que les trois cas de malformations congénitales autres ne se plient pas au modèle trouvé pour les NTD, souligne l'importance qu'il y a à ne pas regrouper à l'intérieur d'un même ensemble toutes les malformations congénitales hétérogènes qui peuvent avoir plusieurs étiologies différentes. Les taux élevés d'IgG chez les mères de NTD et les taux bas d'IgG chez leurs nouveaux-nés concordent avec les études précéden- tes $[20,22]$. Néanmoins, ils ne confortent pas la suggestion que l'hémodilution est la cause des taux bas d'IgG. Nous n'avons pas trouvé de différence significative au niveau des taux d'albumine entre les témoins et les nouveaux-nés avec NTD. En outre, les taux d'albumine avaient tendance à être élevés dans les sérums des mères et des nouveaux-nés du groupe NTD. Une explication du faible taux d'IgG est l'altération de la perméablité placentaire et de la maturation des mécanismes spécifiques de transport des IgG qui impliquent les macrophages placentaires. On a trouvé des taux de macrophages élevés au niveau des placentas [29], et de liquides amniotiques $[10,23,25]$ en provenance de fœtus anencéphales. Cette activité macrophagique anormale peut affecter le processus de maturation ou pourrait être responsable d'une anomalie des mécanismes de transport des IgG.

Les taux élevés d'IgG chez les mères NTD et les taux bas chez leurs nouveaux-nés entraine un ration $M / N$ élevé. Le ratio a été calculé individuellement pour chaque paire mère-nouveau-né ce qui permet d'observer le ratio moyen qui témoigne de la consistance du système mère-fœtus.

A la différence des $\mathrm{IgG}$, les immunoglobulines $M$ ne manifestent pas de différence entre les taux du groupe NTD et les témoins. A l'opposé les nouveaux-nés porteurs d'autres malformations congénitales ont des taux d'IgM significativement élevés et un rapport IgM $M / N$ abaissé. Toutefois, on n'a pas trouvé de différence entre les sérum maternels et des nouveaux-nés en ce qui concerne les taux d'anticorps maternels et des nouveauxnés en ce qui concerne les taux d'anticorps spécifiques pour de nombreux agents infectieux. Un fait est intéressant, à savoir que bien que les 3 cas de malformations congénitales aient accouché à terme, on a trouvé un ratio semblable abaissé dans un groupe d'africains prématurés [4].

Cette étude implique de faibles échantillons, l'importance d'un bon appariement des contrôles et les différences des taux d'Ig dans chaque groupe, tout particulièrement des ratios $M / N$, font que cette étude est une étude préliminarie qui fait ressortir la possibilité d'études ultérieures.

Mots-clés: Immunoglobulines, malformations congénitales, maternal, nouveau-né.

Acknowledgements: We are greatly indebted to Mr. JoHn Dickson, Department of Bacteriology, University of Edinburgh, for performing the complement fixation tests, to A. CAROTHERS and H. MEDINAGomez for their assistance with the statistical analysis.

\section{References}

[1] Batson JL, K Winn, NH Dubin, TH Parmely: Placental immaturity associated with anencephaly. Obstet Gynecol 65 (1985) 846

[2] Bell JE, A Gordon, AFJ Maloney: Abnormalities of the spinal meninges in anencephalic fetuses. J Pathol 133 (1981) 131
[3] BIRCH JM: Anencephaly in stillborn sibs of children with germ cell tumours. Lancet 1 (1980) 1257

[4] BoERSMA ER: Serum immunoglobulins IgG, IgM and IgA in maternal cord blood pairs from infants of normal and low birth weights in Tanzania. Arch Dis Child 56 (1981) 31 
[5] Borner PH, H DeICHER, K HeIDE, J ReINECKE: Evidence for the participation of the Fc portion of immunoglobulin $G$ in materno foetal immunoglobulin transfer in the human. Int Cong Immunol Obstet Gynaecol 327 (1973) 272

[6] BROCK DJH: Feto-specific proteins in pre-natal diagnosis. Mol Aspects Med (1980) 431

[7] CARTER CO: Clues to the aetiology of neural tube malformations. Dev Med Child Neurol 16 (Suppl 32) (1974) 3

[8] Cederqvist LS, S Spingelman, SD Litwin: The fetal serum alpha-feto protein and its relationship to immunoglobulins and birth weight at term. Obstet Gynecol 61 (1983) 233

[9] Chadd MA, OP Gray, JW KeYser: Gammaglobulin levels in newborns with spina bifida cystica. Acta Paediatr Scand 59 (1970) 134

[10] Chapman PA, WK Blenkinsopp, BV Lewin: The detection of neural tube closure defects by exfoliative cytology of amniotic fluid. Acta Cytol (Baltimore) 25 (1981) 367

[11] Coffey VP, WJE JEssop: Maternal influenza and congenital deformities. A follow-up study. Lancet 1 (1963) 748

[12] EMERY JL: Evidence of antigenic active substances in the amniotic fluid in children with open neurospinal dysraphism. Dev Med Child Neurol [Suppl 16] 32 (1974) 154

[13] FAULK WP: Immunology of the materno foetal relationship. In: Fougerau M, J DAusseT: Academic Press, New York 1980

[14] Gitlin D, J Kumate, J Urrusti, C Morales: The selectivity of the human placenta in the transfer of plasma proteins from mother to fetus. J Clin Invest 43 (1964) 1938

[15] Hakosalo J, L Saxen: Influenza epidemic and congenital defects. Lancet 2 (1971) 1346

[16] HAYWARD AR: Development of immune responsiveness. In: FAULKNER F, JM TANNER: Human Growth I. Principles and Prenatal Growth. Bailliere Tindall, London 1978

[17] HURLEY R: Antenatal infections associated with fetal malformations. In: SCRIMGEOUR JB: Towards the Prevention of Fetal Malformation. University Press, Edinburgh 1978

[18] JANDIAL V, H ThOM, J GiBson: Raised alpha-fetoprotein levels associated with minor congenital defects. $1 \mathrm{Br}$ Med J 2 (1976) 22

[19] JoHNSON PM, WP FAULK: Immunological studies of human placentae: Identification and distribution of proteins in immature chorionic villi. Immunology 34 (1978) 1027

[20] KAMRIN BB: Effect of injected human immunoglobulins on fetal rat development, spinal, neural and osseous changes. Anat Rec 173 (1972) 173
[21] Kurtze JF, ID Goldberg, LT KuRLAND: The distribution of deaths from congenital malformations of the nervous system. Neurology 23 (1973) 483

[22] MC KaY E, H THOM, D GraY: Immunoglobulins in umbilical cord plasma. II: Congenital deformities, other abnormalities and multiple pregnancies. Arch Dis Child 42 (1967) 264

[23] Medina-Gomez P, WH MC Bride: Amniotic fluid macrophages from normal and abnormal fetuses. Prenat Diagn 6 (1986) 195

[24] Nevin NC, J Thompson, G Roberts: Raised alphafetoprotein levels and congenital defects. Br Med J 2 (1976) 473

[25] PAPP Z, JE BeLl: Uncultured cells in amniotic fluid from normal and abnormal foetuses. Clin Genet 166 (1979) 282

[26] SChimke RN, C Bolano, CH KirkPatrick: Immunologic defficiency in the congenital rubella syndrome. Am J Dis Child 118 (1969) 626

[27] Soothill JF, K HAYES, JA Dudgeon: The immunoglobulins in congenital rubella. Lancet 1 (1966) 1385

[28] STIEHM ER: Fetal defense mechanisms. Am J Dis Child 129 (1975) 438

[29] TEN BERGE BS: The placenta in anencephaly. Gynaecology 159 (1965) 359

[30] THOM H, E Mc KAY, D GRAY: Immunoglobulins in umbilical cord plasma. I: Healthy infants. Arch Dis Child 42 (1967) 259

[31] VAN der Meulen JA, TC Mc Nabb, N HoEfFnerCavalllon, M Klein, K Dorrington: The Fc gamma-receptor on human placenta plasma membrane. I. Studies on binding of homologous and heterologous immunoglobulin G. J Immunol 124 (1980) 500

[32] Voigtlander T, F Vogel: Low alpha-fetoprotein and serum albumin levels in Morbus Down may point to a common regulatory mechanism. Hum Genet 71 (1985) 276

[33] Yabuki Y, K Sugiura, T Kato: Epidemiologic and etiologic studies on regional high incidence of anencephaly. Acta Obstet Gynecol (Japan) 29 (1977) 913

Received November 12, 1987. Accepted November 23, 1987.
Dr. Patricia Medina-Gómez
Division de Investigacion Biomedica
Instituto Nacional de Perinatologia
Montes Urales 800
11000 Mexico, D. F.
Mexico 